Prepared for the U.S. Department of Energy under Contract DE-AC05-76RL01830

\title{
Project Work
}

Plan 100-N Area Strontium-90

Treatability Demonstration Project:

Phytoremediation Along the $100-\mathrm{N}$

Columbia River Riparian Zone

\section{Ainsworth}

April 2006 


\title{
DISCLAIMER
}

This report was prepared as an account of work sponsored by an agency of the United States Government. Neither the United States Government nor any agency thereof, nor Battelle Memorial Institute, nor any of their employees, makes any warranty, express or implied, or assumes any legal liability or responsibility for the accuracy, completeness, or usefulness of any information, apparatus, product, or process disclosed, or represents that its use would not infringe privately owned rights. Reference herein to any specific commercial product, process, or service by trade name, trademark, manufacturer, or otherwise does not necessarily constitute or imply its endorsement, recommendation, or favoring by the United States Government or any agency thereof, or Battelle Memorial Institute. The views and opinions of authors expressed herein do not necessarily state or reflect those of the United States Government or any agency thereof.

\author{
PACIFIC NORTHWEST NATIONAL LABORATORY \\ operated by \\ BATTELLE \\ for the \\ UNITED STATES DEPARTMENT OF ENERGY \\ under Contract DE-AC05-76RL01830
}

Printed in the United States of America
Available to DOE and DOE contractors from the Office of Scientific and Technical Information,
P.O. Box 62, Oak Ridge, TN 37831-0062;
ph: (865) 576-8401
fax: $(865)$ 576-5728
email: reports@adonis.osti.gov

\begin{abstract}
Available to the public from the National Technical Information Service, U.S. Department of Commerce, 5285 Port Royal Rd., Springfield, VA 22161 ph: (800) 553-6847 fax: $(703) 605-6900$ email: orders@ntis.fedworld.gov online ordering: http://www.ntis.gov/ordering.htm
\end{abstract}

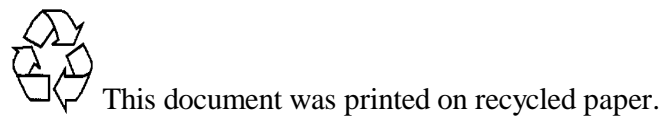


PNNL-SA-49953

\section{Project Work Plan}

\section{0-N Area Strontium-90 Treatability Demonstration Project: Phytoremediation Along the 100-N Columbia River Riparian Zone}

CC Ainsworth

April 2006

Pacific Northwest National Laboratory Operated by Battelle for the U.S. Department of Energy

Richland, Washington 99352 


\section{Contents}

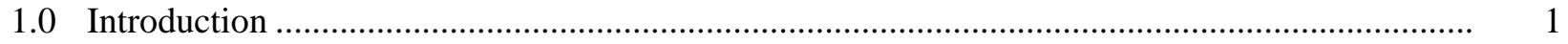

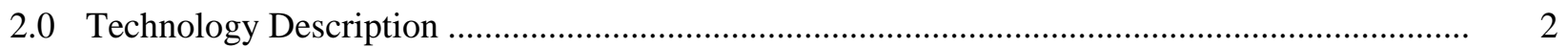

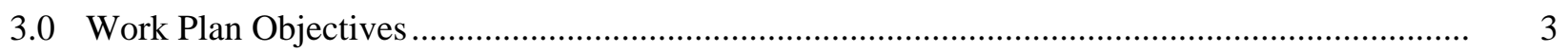

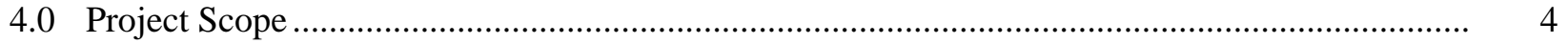

4.1 Task 1: Project Management ........................................................................................ 4

4.2 Task 2: Treatability Test - Experimental Design and Engineering ................................... 4

4.3 Task 3: Greenhouse Fertilization Effects Test .................................................................. 4

4.4 Task 4: Field Treatability Study - Data Collection........................................................ 5

4.5 Task 5: Data Analysis and Reporting ....................................................................... 5

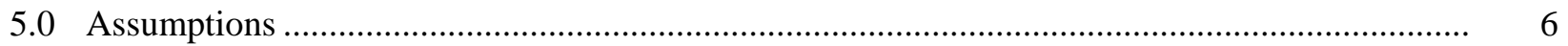

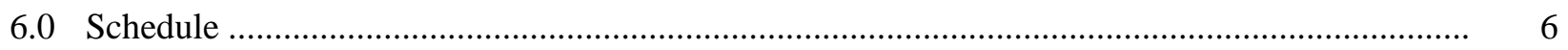

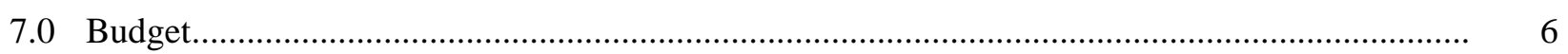

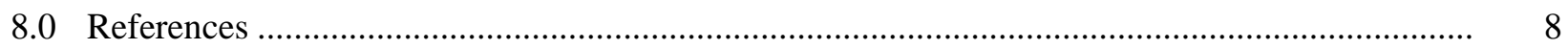

Appendix A - Response to Review Comments and Scope, Schedule, and Costs for Reviewer Suggested Unfunded Studies

\section{Tables}

1 Schedule for the Phytoremediation Treatability Test. 


\subsection{Introduction}

Strontium-90 $\left({ }^{90} \mathrm{Sr}\right)$ exceeds the U.S. Environmental Protection Agency's (EPA's) drinking water standards for groundwater $(8 \mathrm{pCi} / \mathrm{L})$ by as much as a factor of 1,000 at several locations along the $100-\mathrm{N}$ Area. Strontium-90 is present in the aquifer near the river and within the vadose zone of the river's shoreline at 100-N. A radiological survey of shoreline vegetation along the Hanford Reach found areas where the vegetation exhibited elevated levels of radionuclides; of major concern was the 100-N Area where elevated ${ }^{90} \mathrm{Sr}$ was found in a number of species (Antonio et al. 1993; Van Verst et al. 1998; Poston et al. 2000).

The bulk of the ${ }^{90} \mathrm{Sr}$ in the sediments between the bluffs and the river's edge (about $30 \mathrm{~m}$ ) is bound to the sediments in a relatively thin layer that corresponds to the top of the elevated water table formed during the period of active disposal from 1963 to 1991 and the current water table. The layer of contaminated vadose zone is fairly shallow, between 1 and $2 \mathrm{~m}$ thick, between the bluffs and the river's edge. The riparian zone, approximately $10 \mathrm{~m}$ wide, is shallow $(0.2$ to $1.5 \mathrm{~m})$ and contains approximately $1 \mathrm{Ci}$ of ${ }^{90} \mathrm{Sr}$. Strontium (both stable and fission product) is held by the soil/sediment primarily via an ionexchange mechanism that retards ${ }^{90} \mathrm{Sr}$ transport (Serne and LeGore 1996). Its sorption coefficient, or $\mathrm{K}_{\mathrm{d}}$, is between 15 to $40 \mathrm{~mL} / \mathrm{g}$, which means approximately $99 \%$ of the ${ }^{90} \mathrm{Sr}$ is sorbed to the sediment with $1 \%$ associated with the groundwater. Currently, the only remedial action to control ${ }^{90} \mathrm{Sr}$ leaching into the river along the 100-N Area is a pump-and-treat system. Unfortunately, this system is not efficiently nor effectively removing ${ }^{90} \mathrm{Sr}$ from the vadose zone or the groundwater near the river, nor is it controlling ${ }^{90} \mathrm{Sr}$ transport through the river's riparian zone.

Phytoremediation is a managed, remediation technology in which plants or integrated plant/ rhizosphere systems are employed to extract and/or sequester soil contaminants (INEEL 2000). Phytoremediation is designed as an extraction system along the riparian zone of the Columbia River and, in conjunction with a treatment train incorporating monitored natural attenuation and the formation of an apatite barrier (both injection and infiltration modes) is designed to extract/sequester ${ }^{90} \mathrm{Sr}$ currently present or expected to move toward the river over the next 300 years. The phytoremediation system is a polishing step that is directed at extracting ${ }^{90} \mathrm{Sr}$ from the vadose and saturated zone associated with the Columbia River riparian zone. After the apatite barrier is fully functional and ${ }^{90} \mathrm{Sr}$ in the riparian zone has been extracted, the phytoremediation component of the treatment train would be terminated. There is, however, a synergy between the apatite sequestration barrier and the Coyote willow phytoremediation, which arises because an established willow rhizosphere (root zone) will act as a filter (rhizofiltration) of

${ }^{90} \mathrm{Sr}$ from groundwater mobilized during the injection of the apatite solution and ahead of the apatite precipitation front.

The 100-N Area Innovative Treatment and Remediation Demonstration (ITRD) identified phytoremediation as a potential technology both for the removal of ${ }^{90} \mathrm{Sr}$ from the soil of the riparian zone and as a filter for groundwater along the Columbia River. Recent greenhouse and growth chamber studies have demonstrated the viability of phytoextraction to remove ${ }^{90} \mathrm{Sr}$ from this area's soil/water; in conjunction with monitored natural attenuation and an apatite barrier the process would make an effective treatment for remediation of the $100-\mathrm{N}$ Area ${ }^{90} \mathrm{Sr}$ plume. All activities associated with the 100-NR-1 and 100-NR-2 Operable Units of the Hanford 100-N Area have had, and continue to have, significant regulatory and stakeholder participation. Beginning in 1998 with the ITRD process, presentations to the ITRD TAG 
were heavily attended by EPA, Washington State Department of Ecology, and stakeholders. In addition, three workshops have been held to receive regulatory and stakeholder feedback on monitored natural attenuation, the apatite barrier, and phytoremediation; these were held in Richland in August 2003, December 2004, and August 2005. The apatite injection treatability test plan (DOE 2005) describes phytoremediation as a technology to be evaluated during the March 2008 evaluation milestone as described in the Tri-Party Agreement change request (M-16-06-01 Change Control Form). If, during this evaluation milestone, phytoremediation is favorably evaluated it would be incorporated into the treatability test plan. The phytoremediation treatability test described in this proposal is strongly supported by the Washington State Department of Ecology.

\subsection{Technology Description}

The presently proposed technology is based on the use of plants, specifically Coyote willow (Salix exigua), to extract ${ }^{90} \mathrm{Sr}$ from the vadose zone soil and aquifer sediments (phytoremediation) and filter ${ }^{90} \mathrm{Sr}$ (rhizofiltration) from the shallow groundwater along the riparian zone of the Columbia River. The 100-N Area riverbank is a unique environment. The area is (1) dominated by course-grained sands, (2) subjected to significant daily fluctuations in groundwater level, and (3) covered with rip-rap. In this environment, implementation of a phytoremediation strategy requires a plant with roots capable of invading the saturated zone and with an inherent ability to tolerate water-table fluctuations. Coyote willow is a perennial native shrub that grows along the Columbia River throughout the Hanford Site and MidColumbia region. As a phreatophyte, its root system readily invades the saturated zone and tolerates prolonged flooding. The plant is easily propagated by above-ground cuttings, spreads by lateral root suckers (minimizing planting problems), and is amenable to multiple harvests in a given year without the need to replant. Similar species, Salix viminalis, and Salix dasyclados, have been used in Europe and the United States as a bioenergy source (von Fricks et al. 2002; Adegbidi et al. 2001 and references therein) because of their rapid growth potential; biomass production of the latter species have been as high as 20-30 metric tons per ha.

The use of phytoremediation/rhizofitration at the 100-N Area is part of a treatment train that includes monitored natural attenuation (MNA) and an apatite barrier. Most of 3,000 curies (Ci) of ${ }^{90} \mathrm{Sr}$ that were discharged to liquid waste disposal facilities at the 100-N Area is held in the vadose zone and saturated zone behind the bluffs. Because of ${ }^{90} \mathrm{Sr}$ radioactive decay $\left(\mathrm{t}_{1 / 2}=28.6 \mathrm{yr}\right)$ and sediment retardation, this will dissipate prior to reaching the river. The placement of an injected upgradient apatite barrier is being designed and tested to halt (by sequestration) the transport of ${ }^{90} \mathrm{Sr}$ into the river's riparian zone and river proper. Phytoremediation would act as an immediate interceptor of aqueous ${ }^{90} \mathrm{Sr}$ currently within the riparian zone's pore water and a longer term extractor of ${ }^{90} \mathrm{Sr}$ currently sorbed to the riparian zone's vadose and aquifer sediment. Without the ability to prevent future transport of ${ }^{90} \mathrm{Sr}$ into the riparian zone (barrier placement), phytoremediation would not be an appropriate remediation technology. Combined with the barrier, it could be an effective, low cost/maintenance remediation technology (DOE 2005).

Once established along the riparian zone (about 6 months to a year), the willows would be harvested twice a year - in June prior to high water and in November prior to winter senescence. Harvested material would be disposed of in an appropriate manner (ERDF landfill). The growth and harvest cycle continues over the life of the phytoremediation process, which could last between 5 and 7 years 
depending on the extraction rate and the proximity of the infiltrated apatite barrier. The range of time required for ${ }^{90} \mathrm{Sr}$ removal depends on the placement of the apatite barrier. The reduction in remediation time results in part from a synergistic interaction between an established phytoremediation zone and the placement of an infiltrated apatite barrier. This synergy results because (1) the microbial ecology (diversity/population) associated with the willow's rhizosphere (root zone) will be orders of magnitude greater than the original (non-planted) vadose and saturated zone, thereby decreasing the need to stimulate the indigenous microbial growth with nutrient injections; (2) the established rhizosphere will act as a filter (rhizofiltration) during injection, extracting ${ }^{90} \mathrm{Sr}$ from groundwater that will be mobilized during the injection of the apatite solution and ahead of the apatite precipitation front; (3) as apatite is precipitated, ${ }^{90} \mathrm{Sr}$ present locally (in solution and exchanged) will be sequestered (co-precipitated) by the forming apatite solid phase; and (4) the willows will act as bio-monitors for sequestration by apatite, that is, as apatite sequestration occurs ${ }^{90} \mathrm{Sr}$ concentrations in the above ground plant tissue will begin to decrease with successive harvests; at a predetermined tissue concentration (currently set at $0.5 \mathrm{nCi} / \mathrm{g}$ dry tissue weight) the phytoremediation portion of the treatment train will be terminated.

The primary determinant for the required remediation, besides the volume of sediment to be treated, is biomass production. This is dependent on planting density, fertilization, and other management practices (Hawthorne 1968; Ehlken and Kirchner 1996). While willow shrubs cultivated for bioenergy have obtained yields of between 20 and 30 metric tons per ha, greenhouse studies conducted under conditions similar to those expected within the riparian zone suggest that the maximum yield for Coyote willow would be about 15 metric tons/ha. Using optimal fertilization practices, yields are expected to be between 10 and 12 metric tons/ha once the willow coppice is established along the river's riparian zone. The number of years required for successful amelioration of ${ }^{90} \mathrm{Sr}$ from the river's riparian zone noted above is based on this latter yield potential for Coyote willow.

Coyote willow is currently being used extensively along the Columbia and Yakima Rivers for bank stabilization and revegetation proposes. Simple stem cuttings (about 40 to $100 \mathrm{~cm}$ in length) are driven into the ground around and within the rip rap. Leaf and root buds appear within two weeks and robust growth (depending on temperature and fertility) occurs rapidly. For the purposes of phytoremediation, harvesting is accomplished simply by clipping the stem about 10 to $20 \mathrm{~cm}$ above the ground; regrowth is rapid given the proper conditions.

\subsection{Work Plan Objectives}

The major objectives of this study are to (1) determine the most efficient fertilization method for Coyote willow that will generate the greatest biomass possible while protecting the Columbia River from excess nutrient runoff, and (2) demonstrate the efficacy of using Coyote willow as a ${ }^{90} \mathrm{Sr}$ phytoremediation tool along the riparian zone associated with the 100-N Area of the Hanford Site. In performing these two tasks, the additional benefits accrued will be (1) accelerating the Columbia River 100-N Area corridor cleanup, and (2) developing alternatives to the existing pump-and-treat system as specified in the interim record of decision (ROD) (EPA 1999) for ${ }^{90} \mathrm{Sr}$ in the $100-\mathrm{N}$ Area. 


\subsection{Project Scope}

The following five work elements will form the scientific basis for the proposed treatability study of phytoremediation of ${ }^{90} \mathrm{Sr}$ along the Columbia River's riparian zone.

\subsection{Task 1: Project Management}

Plan, organize, and provide top-level guidance and direction for overall project performance. Also provide project-level cost and schedule control, tracking, and reporting. Coordinate the Columbia River Protection Supplemental Technologies Project work scope with DOE, Richland Operations, the Groundwater Remediation and Closure Assessment Project, and the Office of River Protection, including participation in planning, peer reviews, and periodic project meetings.

\subsection{Task 2: Treatability Test - Experimental Design and Engineering}

This work element consists of design and implementation of the treatability test field plot. Available site hydrologic and geochemical data will be reviewed within the context of identifying the best available location for the field test plot. Concomitantly, the experimental design (plot size, planting number, etc.) and engineering for the test field plot (barriers) will be drawn up. Once site-specific characterization data, and proposed design and engineering specifications are available, a field test plan will be prepared. The plan will provide information and descriptions of potential site location and engineering, planned test activities, sampling (of water, sediment, and plant tissue) schedule, methods, and data quality requirements.

\subsection{Task 3: Greenhouse Fertilization Effects Test}

This work element will be conducted in the greenhouse. Plant uptake of calcium (Ca) and $\mathrm{Sr}\left({ }^{90} \mathrm{Sr}\right.$ follows the $\mathrm{Sr}$ behavior) is a function of plant growth and nutritional status. Maintenance or enhancement of an optimal growth rate depends on the adequate supply of essential nutrients such as phosphate $(\mathrm{P})$ and nitrogen $(\mathrm{N})$ to the willow. Soil application of fertilizer along the banks of the river could permit loss to the water and damage to the surrounding fauna. Therefore, controlled foliar application of nutrients to enhance the rate and uptake of $\mathrm{Sr}$ (and therefore ${ }^{90} \mathrm{Sr}$ ) will be used. Technical issues that will be evaluated focus on application rate, timing, and frequency of foliar application. All experiments will use a non-contaminated soil that mimics the hydrologic and geochemical characteristics of the 100-N Area riparian zone.

- Pre-Test Delineation of Fertility Levels. Several university experiment stations in the United States and Europe are experimenting with related species of willow for biomass/bioenergy production. Work previously performed in these experiments will be used to narrow the level of fertility needed in the pre-test application that will evaluate several commercially available foliar fertilizer formulations. This test will require about 3 to 6 weeks and utilize 5 plant replicates raised in the greenhouse in 1-gal free-draining pots. Plants will be grown for 30 to 45 days with foliar fertilization as suggested by the manufacturer. After a suitable growth period individual plants will be harvested, biomass (fresh and dry) determined, and dried mass analyzed for nutrient status (and $\mathrm{Sr})$. 
- Full-Scale Fertility Test. This experiment will evaluate the application rate of fertilizer, timing (plant stage of first application versus use of a tree fertilizer spike), and frequency of fertilizer treatment. This experiment will be conducted as a modified factorial design that investigates the above factors, and will require a total of 60 plants. The new cuttings will be planted in soil (one plant per 1-gal pot). With time the individual pot's position along the greenhouse bench will be rotated periodically to avoid light distribution differences. Plants will be grown for 45 days and watered throughout with a synthetic groundwater that mimics $100-\mathrm{N}$ groundwater.

The modified factorial design is currently designed as follows:

1) Application rates of a foliar fertilizer, at either a factor of 0.5 or 1.0 of the manufacturer's recommended rate, will be evaluated.

2) Timing of initial fertility treatment will evaluate the impact of using a tree spike (commercially available e.g., Jobe's Tree Spikes) versus an initial foliar fertilizer application at the tri-leaf stage of growth followed by regular fertilizer application.

3) Frequency of foliar fertilizer application will be evaluated using two periodic fertilization routines of every 2 weeks or every 4 weeks.

4) Two zero fertilizer application control sets (6 reps, 5 plants each) will be followed throughout the study; these will receive either no fertilization or only receive the tree fertilizer spike.

After the 45 day growth period, individual plants will be harvested, biomass (fresh and dry) determined, and dried mass analyzed for nutrient status (and $\mathrm{Sr}$ ).

\subsection{Task 4: Field Treatability Study - Data Collection}

The exact nature of this work element will depend on the outcome of Task 2 (Treatability Test Experimental Design and Engineering) field work plan. This plan will designate the site location, site size (physical and number plants), barriers, sampling, methodologies, and data quality requirements. However, currently it is expected that 25 to 50 plants will be planted within a field site no larger than $10 \mathrm{~m} \times 3 \mathrm{~m}$. After planting the Coyote willow cuttings, the site will be inspected at least four times a week and estimates of leaf litter determined and then policed. Over the next 1.5 years, the above ground portion of all plants will be harvested twice per year, biomass determined, and $\mathrm{Ca}$ and $\mathrm{Sr}$ content determined. Additional monitoring will include vegetation sampling (stem and leaves), and occasional removal of roots to determine whole plant $\mathrm{Ca} / \mathrm{Sr}$ uptake and partitioning. Simultaneous measurement of soil and soil pore water chemical composition from above within and below the groundwater flow path through the willow coppice root zone will also be conducted to monitor for potential changes in solid phase and aqueous phase $\mathrm{Ca}$ and $\mathrm{Sr}$ concentrations, or the $\mathrm{Ca} / \mathrm{Sr}$ concentration ratio. Groundwater sampling, accessed through project emplaced lysimeters, will occur on monthly intervals over the study's duration. This task will lead to performance assessment.

\subsection{Task 5: Data Analysis and Reporting}

This work element consists of managing, compiling, and evaluating all of the data generated during the treatability studies and preparing a treatability test report. The final report will cover activities 
ranging from basic greenhouse development work through the field-scale demonstration of the technology. Findings presented in this report will form the basis of an evaluation of this technology for full-scale implementation during the feasibility study process.

\subsection{Assumptions}

The following assumptions pertain to this scope of work:

- No project specific Quality Assurance Plan (QAP) will be required; work will be conducted under the Groundwater Performance Assessment Project QAP

- A suitable test site can be identified along the Columbia River shoreline that is proximal to the $100-\mathrm{N}$ Area and is not contaminated with radioactive materials (i.e., ${ }^{90} \mathrm{Sr}$ ).

- Fluor Hanford, Inc. will be able to provide construction services for the project according to the proposed schedule.

- The schedule shown in this proposal will be approved by DOE and the appropriate regulatory agencies.

- The project will start on or before May 15, 2006.

\subsection{Schedule}

A detailed schedule for the phytoremediation treatability test is provided in Table 1 .

\subsection{Budget}

The total budget for this plan is estimated to be approximately $\$ 433,000$. 
Table 1. Schedule for the Phytoremediation Treatability Test

\begin{tabular}{|c|c|c|c|c|c|c|c|c|c|c|c|c|c|c|c|c|c|c|c|c|c|c|c|c|c|c|c|}
\hline \multirow{3}{*}{$\begin{array}{c}\text { Phytoremediation } \\
\text { Treatability Study } \\
\text { Activities }\end{array}$} & \multirow{3}{*}{$\begin{array}{l}\text { Start } \\
\text { Date } \\
\end{array}$} & \multirow{3}{*}{$\begin{array}{c}\text { Finish } \\
\text { Date } \\
\end{array}$} & \multicolumn{5}{|c|}{ Fiscal Year 2006} & \multicolumn{12}{|c|}{ Fiscal Year 2007} & \multicolumn{8}{|c|}{ Fiscal Year 2008} \\
\hline & & & \multirow[b]{2}{*}{ May } & \multirow[b]{2}{*}{ Jun } & \multirow[b]{2}{*}{ Jul } & \multirow[b]{2}{*}{ Aug } & \multirow[b]{2}{*}{ Sept } & \multirow[b]{2}{*}{ Oct } & \multirow[b]{2}{*}{ Nov } & \multirow[b]{2}{*}{ Dec } & \multirow[b]{2}{*}{ Jan } & \multirow[b]{2}{*}{ Feb } & \multirow[b]{2}{*}{ Mar } & \multirow[b]{2}{*}{ Apr } & \multirow[b]{2}{*}{ May } & \multicolumn{2}{|c|}{2007} & \multirow[b]{2}{*}{ Aug } & \multirow[b]{2}{*}{ Sept } & \multirow[b]{2}{*}{ Oct } & \multirow[b]{2}{*}{ Nov } & & & & 2008 & & \\
\hline & & & & & & & & & & & & & & & & Jun & Jul & & & & & Dec & Jan & Feb & Mar & Apr & May \\
\hline Project Management & $515 / 2006$ & $5 / 31 / 2008$ & & & & & & & & & & & & & & & & & & & & & & & & & \\
\hline Project Management & DIJ/2000 & $5 / 31 / 2008$ & & & & & & & & & & & & & & & & & & & & & & & & & \\
\hline & & & & & & & & & & & & & & & & & & & & & & & & & & & \\
\hline Experimental Design \& & $5 / 15 / 2006$ & $7 / 31 / 2006$ & & & & & & & & & & & & & & & & & & & & & & & & & \\
\hline Enigneering & & & & & & & & & & & & & & & & & & & & & & & & & & & \\
\hline Site construction & & & & & & & & & & & & & & & & & & & & & & & & & & & \\
\hline & & & & & & & & & & & & & & & & & & & & & & & & & & & \\
\hline Greenhouse Tests & & & & & & & & & & & & & & & & & & & & & & & & & & & \\
\hline Pre-test fertility levels & $5 / 30 / 2006$ & $7 / 30 / 2006$ & & & & & & & & & & & & & & & & & & & & & & & & & \\
\hline Full scale fertility test & $7 / 15 / 2006$ & & & & - & & E & & & & & & & & & & & & & & & & & & & & \\
\hline & & & & & & & & & & & & & & & & & & & & & & & & & & & \\
\hline Field Treatability Study - & $8 / 31 / 2006$ & $5 / 31 / 2008$ & & & & & & & & & & & & & & & & & & & & & & & & & \\
\hline Data Collection & & & & & & & & & & & & & & & & & & & & & & & & & & & \\
\hline $\begin{array}{r}\text { Harvests } \\
\end{array}$ & & & & & & & & & 1 & & & & & & & 2 & & & & & 3 & & & & & & 4 \\
\hline water sampling & & & & & $*$ & $*$ & $*$ & $*$ & $*$ & $*$ & $*$ & $*$ & $*$ & $*$ & $*$ & $*$ & $*$ & $*$ & $*$ & $*$ & $*$ & $*$ & $*$ & $*$ & $*$ & $*$ & $*$ \\
\hline sediment sampling & & & & & $\mathbf{a}$ & & & & $\mathbf{b}$ & & & & & & & c & & & & & d & & & & & & e \\
\hline & & & & & & & & & & & & & & & & & & & & & & & & & & & \\
\hline & & & & & & & & & - & & & & & & & & & & & & & & & & & & \\
\hline Data Analysis \& Reporting & & & & & & & & & & & & & & & & & & & & & & & & & & & \\
\hline
\end{tabular}




\subsection{References}

Adegbidi HG, TM Volk, EH White, LP Abrahamson, RD Briggs, and DH Bickelhaupt. 2001. "Biomass and Nutrient Removal by Willow Clones in Experimental Bioenergy Plantations in New York State." Biomass Bioenergy 20:399-411.

Antonio EJ, TM Poston, and WH Rickard, Jr. 1993. Radiological Survey of Shoreline Vegetation from the Hanford Reach of the Columbia River, 1990-1992. PNL-8797, Pacific Northwest National Laboratory, Richland, Washington.

DOE. 2005. Strontium-90 Treatability Test Plan for 100-NR-2 Groundwater Operable Unit. DOE/RL-2005-96, Draft A, U.S. Department of Energy, Richland, Washington.

Ehlken S and G Kirchner. 1996. "Seasonal Variations in Soil-to-Grass Transfer of Fallout Strontium and Cesium and of Potassium in North German Soils." J. Environ. Radioactivity 33:147-181.

EPA. 1999. Interim Action Record of Decision for the U. S. Department of Energy Hanford 100-NR-1 and 100-NR-2 Operable Units Interim Remedial Actions. EPA/ROD/R10-99/112, U.S. Environmental Protection Agency, Region 10, Seattle, Washington.

Federal Facility Agreement and Consent Order Change Control Form (Tri-Party Agreement), change number M-16-06-01, U.S. Department of Energy, Richland, Washington.

Hawthorne HA. 1968. Effect of Ammonium Nitrate on the ${ }^{90} \mathrm{Sr}$ Concentration in Tomato Organs. USAEC Report UCLA-12-772, University of California, Los Angeles, California.

INEEL. 2000. Proceedings from the Workshop on Phtyoremediation of Inorganic Contaminants. INEEL/EXT-2000-00207, February 2000, November 30 - December 2, 1999, Argonne National Laboratory, Chicago, Illinois, Idaho National Engineering and Environmental Laboratory, Idaho Falls, Idaho.

Poston TM, RW Hanf, and RL Dirkes (eds.). 2000. Hanford Site Environmental Report for Calendar Year 1999. PNNL-13230, Pacific Northwest National Laboratory, Richland, Washington.

Serne RJ and VL LeGore. 1996. Strontium-90 Adsorption-Desorption Properties and Sediment Characterization at the 100-N Area. PNL-10899, Pacific Northwest National Laboratory, Richland, Washington.

Van Verst SP, CL Albin, GW Patton, and ML Blanton. 1998. Survey of Radiological Contaminants in the Near-Shore Environment at the Hanford Site 100-N Reactor Area. PNNL-11933, Pacific Northwest National Laboratory, Richland, Washington.

von Fricks Y, K Rosen, and L Sennerby-Forsse. 2002. "Uptake and Distribution of ${ }^{137} \mathrm{Cs}$ and ${ }^{90} \mathrm{Sr}$ in Salix viminalis Plants.” J. Environ. Radioact. 63:1-14. 


\section{Appendix A}

\section{Response to Reviewer Comments and Scope, Schedule, and Costs for Reviewer Suggested Unfunded Studies}

Table A.1 contains the responses to reviewer comments. The scope, schedule, and costs for reviewer suggested unfunded studies are exhibited below.

Table A.1. Matrix of Review Evaluation Comments, Comment Elaboration, and Response (while the review panel supported the proposal, there were four comments that needed to be addressed)

\begin{tabular}{|c|c|c|}
\hline Review Comments & Description & Response \\
\hline $\begin{array}{l}\text { 1) Sequencing of } \\
\text { technologies - } \\
\text { Apatite injection } \\
\text { and } \\
\text { Phytoremediation }\end{array}$ & $\begin{array}{l}\text { Reviewers expressed } \\
\text { concern that a) } \\
\text { infiltration of apatite } \\
\text { forming solution could } \\
\text { adversely impact } \\
\text { Coyote willows } \\
\text { during/after } \\
\text { infiltration, b) if } \\
\text { groundwater ratio of } \\
\mathrm{Ca} / \mathrm{Sr}(\mathrm{aq}) \text { increases as } \\
\text { a result infiltration will } \\
\text { the willows take up } \\
\text { less Sr, and c) is this a } \\
\text { temporary } \\
\text { phenomenon. }\end{array}$ & $\begin{array}{l}\text { While these are excellent suggestions, they were not part of } \\
\text { the original proposed scope. Our original assessment was } \\
\text { that the addition of } \mathrm{Ca} \text { was not the main concern because the } \\
\mathrm{Ca} \text { would be infiltrated as the } \mathrm{Ca} \text { - citrate complex, and as the } \\
\text { complex disassociated the } \mathrm{Ca} \text { would precipitate as apatite. } \\
\text { The bigger concern was the infiltration of substantial Na } \\
\text { concentrations which would increase the aqueous phase } \\
\text { concentration of } \mathrm{Sr} \text { and }{ }^{90} \mathrm{Sr} \text { resulting from Na exchanging } \\
\text { with the } \mathrm{Sr} \text { and }{ }^{90} \mathrm{Sr} \text { on the sediments cation exchange sites } \\
\text { where approximately } 85 \% \text { to } 90 \% \text { of the } \mathrm{Sr} \text { and }{ }^{90} \mathrm{Sr} \text { in the } \\
\text { sediment resides. In addition, the impact of elevated Na } \\
\text { concentrations may adversely effect biomass production. } \\
\text { However, these assumptions have not been thoroughly tested. } \\
\text { If we were to include tests that address these issues in the } \\
\text { current scope, the additional cost would be } \sim \$ 123 \mathrm{~K} \text { (see } \\
\text { appendix A-2 scope, schedule, and cost for task } 6 \text { ). }\end{array}$ \\
\hline $\begin{array}{l}\text { 2) Identification of } \\
\text { performance } \\
\text { metrics }\end{array}$ & $\begin{array}{l}\text { This comment actually } \\
\text { arises from two } \\
\text { connected comments: } \\
\text { a) what data will be } \\
\text { collected during the } \\
\text { demonstration, and b) } \\
\text { the development of } \\
\text { end-point criteria. }\end{array}$ & $\begin{array}{l}\text { The proposed field demonstration data collection included } \\
\text { water (on a monthly basis), sediment (on a quarterly basis), } \\
\text { and willow tissue analyses (at midpoint and harvest times); } \\
\text { these are in accord with reviewer suggestions. Because the } \\
\text { field demonstration is not being conducted in a contaminated } \\
\text { area end-point criteria was not placed in the proposal. From } \\
\text { previous work in the greenhouse and growth chamber, the } \\
\text { estimated end-point metric from willow tissue analysis is > } \\
\text { 5nCi/g dry wt. While this metric will continue to be evaluated } \\
\text { during the proposed field work, the }>5 \mathrm{nCi} / \mathrm{g} \text { dry wt end-point } \\
\text { is believed to be nearing a point below which extraction } \\
\text { efficiency is of limited benefit. In addition, the estimated } \\
\text { detection limit for }{ }^{90} \mathrm{Sr} \text { in plant tissue is approximately } \\
0.25 \mathrm{nCi} / \mathrm{g} \text { dry wt., which means that the current end-point (> } \\
5 \mathrm{nCi} / \mathrm{g} \text { dry wt) is currently a factor of } 10 \text { greater than the } \\
\text { lowest quantifiable limit }(0.5 \mathrm{nCi} / \mathrm{g} \text { dry wt). } \\
\text { This effort is within the current scope of work. }\end{array}$ \\
\hline
\end{tabular}


Table A.1. (contd)

\begin{tabular}{|c|c|c|}
\hline Review Comments & Description & Response \\
\hline $\begin{array}{l}\text { 3) Perform tests to } \\
\text { better understand } \\
\text { potential collateral } \\
\text { impacts of the } \\
\text { phytoremediation } \\
\text { system. }\end{array}$ & $\begin{array}{l}\text { Collateral impacts } \\
\text { relate to a) off-site } \\
\text { release of plant } \\
\text { material (leaves, twigs, } \\
\text { etc.), b) management } \\
\text { of contaminated plant } \\
\text { materials, and c) food- } \\
\text { chain transfer. }\end{array}$ & $\begin{array}{l}\text { The current scope of work includes testing management } \\
\text { methods of minimizing off-site release of plant materials } \\
\text { including physical barriers, timed policing of the willow } \\
\text { coppice, and timed harvesting prior to pollen or catkin } \\
\text { formation. Biomass harvesting will be conducted by hand - } \\
\text { one plant at a time - to minimize any potential off-site transfer } \\
\text { of biomass. However, management of harvesting, tissue } \\
\text { sampling (leaves, and stems) and waste packaging will be } \\
\text { looked at critically to identify best management practices that } \\
\text { limit/exclude potential for off-site transfer. These efforts are } \\
\text { currently in the scope of work. } \\
\text { Food-chain transfer is not currently within the scope of } \\
\text { work, however, literature reviews conducted in the past and } \\
\text { design of any willow barrier suggests that plant to insect } \\
\text { transfer is currently not well delineated. Experiments to test } \\
\text { this vector have been planned since } 1998 \text { but not performed. } \\
\text { The cost of incorporating these studies into the current scope } \\
\text { is } \sim \$ 182 \mathrm{~K} \text {. (see appendix A-3 for scope, schedule, and cost } \\
\text { for task 7). }\end{array}$ \\
\hline $\begin{array}{l}\text { 4) Ensure estimated } \\
\text { lifecycle costs are } \\
\text { realistic. }\end{array}$ & $\begin{array}{l}\text { The proposal estimated } \\
\text { lifecycle costs for a } \\
\text { phytoremediation } \\
\text { remedial action for } 30 \\
\text { years would be } \\
\$ 1600 \mathrm{~K} \text {. }\end{array}$ & $\begin{array}{l}\text { The reviewers were correct in pointing out that this lifecycle } \\
\text { cost was exceedingly optimistic. In fact there was an error in } \\
\text { this section of the proposal. The estimated lifecycle should } \\
\text { have been } 5 \text { to } 7 \text { years excluding the cost of engineering the } \\
\text { willow coppice } 100 \mathrm{~m} x 10 \mathrm{~m} \text {, and only if phytoremediation } \\
\text { was implemented in conjunction with the apatite infiltration. } \\
\text { Given these constraints and that the implementation would not } \\
\text { occur until FY2008 (at the earliest, the lifecycle cost would } \\
\text { likely be } \$ 2000 \mathrm{~K} \text { excluding the willow coppice construction } \\
\text { costs }(\$ 300 \mathrm{~K}) \text {. }\end{array}$ \\
\hline
\end{tabular}

